\title{
Showman, shaman, or charlatan ... conflicting motives for the media medic?
}

\author{
Michael Shooter
}

One of the few joys of moving house, is the rediscovery of books you haven't opened for years. I was sitting among the dust-sheets rereading Francis Wyndham's anthology of criticism (Wyndham, 1991), when I came across his description of the erstwhile Blue Angel going through yet another reincarnation on the stage of the Queen's Theatre in 1973.

Wyndham marvels at the technical competence of her performance and the audience's wish to be taken in by it but "to these necessary elements," he writes, "Marlene Dietrich adds a third - the mysterious force of her belief in her own magic. Those who find themselves unable to share this belief tend to blame themselves rather than her."

It set me thinking about those other showbiz phenomena - the media medics - and the way they have come to dominate the airwaves, all teeth and T-shirts. Are we so altruistic (and I feel the need to include myself here, albeit gummy and less trendily dressed) as to throw ourselves to the wolves in the sole interest of our patients? We nurse our dreams of stardom, like those Irish singing bars where the next one to be thrust into the limelight protests an inability to utter a note while simultaneously bracing himself to deliver an oratorio!

In all of us, I guess, lies a clash between the serious wish to use the media in the cause of psychiatry and its clients and the secret desire to be an entertainer - with all the theatrical 'sleight of hand', playing on the audience's wish to believe, that it might entail. But is that so radical a departure in the history of medicine? As psychiatrists in the studio, are we not the direct descendants of the shaman, casting bones of insight among the Celtic twilight? "Someone who, through trance and ecstacy, enters other states of being to that in which he or she usually lives, returning with news from which all of humanity (as represented by the tribe) can benefit." (Matthews, 1991).

Are not the family therapists with their messages from the team (safely closeted behind the one-way screen) the latter-day Delphic Oracle, where Pythia intoned Apollo's wishes in such hypnotic rapture that regiments of priests were needed to interpret the message from the vapours? And analysis? In his essay on 'Psychoanalysis and Idolatory' (Phillips, 1993), Adam Phillips finds it ironic that such a "Godless Jew" as Freud should have crammed his consulting room with sacred pottery figurines. "So what was Freud telling his patients and himself by displaying his collection in the rooms where he practised psychoanalysis, a theory and a therapy that was consistently an impassioned critique of religious belief?" No irony here: analysis is not the antithesis of religion but a rival faith. In what better context to deliver the sermon from the unconscious than this shrine to the ancient deities?

The point of all this, I suppose, is that 'healing' from time immemorial has required the same skills on the part of the healer, the same act of faith on the part of the healed, and the same sprinkling of magic cast over its delivery. Not only may that magic not be unethical, it may be necessary to the cure. The best therapist I have ever seen was an Orthodox priest, sitting in pomp in a sumptuously carpeted, onion-domed monastery, in the middle of a frozen Romanian lake, dispensing instant interpretations with a pat of a bejewelled hand on the heads of the halt and the lame. They had queued for hours in an increasingly hysterical state. Oh, bring back the old-style out-patient foyer, overflowing with expectancy like Ellis Island! We ignore the 'apostolic function' at our peril. 
The problem comes, of course, when the media-medic becomes so obsessed with the necessary theatre of the studio that he ignores the tail-end of Wyndham's warning and starts blaming the audience for any resistance to the message. The ability of the showman-shaman, just like his Celtic predecessors, to carry the audience first out of itself (by the entertainment of the process) then further into its own psyche (by the healing advice imparted) is a modern skill built on solid traditional practices. But it can all too easily become an end in itself. For the charlatan, the medium really is the message.

This is, after all, the Theatre of Embarrassment. Wyndham's very next essay is on P. J. Proby. Proby (aka Jim Smith, the Texas oil-man's son with pony-tailed pretensions), as I am sure you will remember, was the man once tipped for pop-star idolatory or humiliation. He chose the latter, by splitting his trousers on the more prurient stage of the Cavendish Club in Sheffield. And I should know ... I was there!

\section{References}

MATtHEWS, J. (1991) The Celtic Shaman: a handbook Shaftesbury, Dorset: Element Books.

PHILLPS, A. (1993) On Kissing. Tickling and Being Bored London: Faber \& Faber.

WYNDHAM, F. (1991) The Theatre of Embarrassment. London: Chatto \& Windus.

Michael Shooter, Consultant in Child \& Adolescent Psychiatry, Gwent Community Health Trust, Ty Bryn Adolescent Unit, St Cadoc's Hospital, Caerleon, Newport, Gwent NP6 $1 X Q$

\title{
11 th Pan African Psychiatric Conference
}

\author{
O. O. Famuyiwa
}

The Association of Psychiatrists in Africa has re-emerged after 11 years of dormancy, related to communications problems, migration of African psychiatrists to overseas centres and the demoralising impact of Africa's sociopolitical miasma.

The Nigeria chapter initiated the 11th Pan African Psychiatric Conference, held in Lagos from 20-25 November 1994. The main theme 'Socio-economic changes and mental health in Africa', was eloquently debated and the salient observations distilled in a communiqué. Subthemes included biological psychiatry, primary care, manpower and resources allocation and the 'home-bred' so-called transcultural disorders. A World Health Organisation delegation made important contributions on nosology and classification.
Forty-five papers were presented - about six times the number read at the first conference in 1961, held in Abeokuta, Nigeria.

The representation of South Africa at the meeting caused considerable excitement and might have instigated the proposition to hold the next conference in that country in 1998 or before.

The conference curtain fell with the setting up of a non-statutory interim executive charged with the task of mobilising members across Africa and beyond to carving a fresh niche for the Association.

O. O. Famuyiwa, Associate Professor of Psychiatry, College of Medicine, Lagos University Teaching Hospital, PMB 12003, Lagos, Nigeria 